\title{
INFLUENCE OF THE GENOTYPE ON THE ANTHOCYANIN COMPOSITION, ANTIOXIDANT CAPACITY AND COLOR OF CHILEAN POMEGRANATE (Punica granatum L.) JUICES
}

\author{
Elena Sepúlveda ${ }^{1 *}$, Carmen Sáenz ${ }^{1}$, Álvaro Peña1, Paz Robert ${ }^{2}$, Begoña Bartolomé ${ }^{3}$, \\ and Carmen Gómez-Cordovés ${ }^{3}$
}

\begin{abstract}
The bioactive compounds content in pomegranate (Punica granatum L.) juice is variable and depends on agronomic factors, genetic and fruit maturity. In Chile, the areas with this crop have increased more than $65 \%$ in the last 5 years. This paper aims to determine the phenolic composition, antioxidant capacity and chromatic parameters of juices from eight Chilean pomegranate genotypes (PG2 to PG9), containing red (PG2 to PG6) or pink arils (PG7 to PG9). Color, total polyphenol content (using Folin-Ciocalteu reagent), total anthocyanins (by differences in absorbance at different pHs of the juice) and antioxidant capacity (oxygen-radical absorbance capacity, ORAC) were determined. Anthocyanins were identified and quantify using HPLC-DAD and HPLC/ESI-MS, the results were expressed as cyanidin-3-glucoside. ANOVA was used for establish differences between total polyphenols (TP), antioxidant capacity, total anthocyanins (TA), total polyphenols/total anthocyanins relations (TP/TA) and colour parameters. Statgraphics plus 7.0 was used. Genotypes PG2-PG6 (red arils) showing higher values for total polyphenols (1055$\left.1280 \mathrm{mg} \mathrm{L}^{-1}\right)$ and anthocyanins (588-1328 $\left.\mathrm{mg} \mathrm{L}^{-1}\right)$ and higher ORAC values (21.2-24.4 $\left.\mu \mathrm{mol} \mathrm{Trolox} \mathrm{mL}^{-1}\right)$ than the pink arils PG7-PG9 (12.7-16.8 $\mu \mathrm{mol}$ Trolox $\mathrm{mL}^{-1}$ ) values. The latter genotypes showed the highest values of $\mathrm{pH}$ (3.5-3.7). The anthocyanin compounds identified in the juices were the 3-glucoside and 3,5-diglucoside derivatives of delphinidin, cyanidin and pelargonidin. Differences in their relative amounts were found among the Chilean pomegranate genotypes studied. The relationships between TP/TA and Pg/Cy (pelargonidin 3-glucoside and pelargonidine 3,5-diglucoside/cyanidin 3-glucoside and cyanidin 3,5-diglucoside) could be useful in the analytical characterization of Chilean pomegranate genotypes, as well as in the differentiation with other juices containing anthocyanins.
\end{abstract}

Key words: Punica granatum, polyphenols, bioactive compounds.

\section{INTRODUCTION}

Pomegranate fruit (Punica granatum L.) originated from the Middle East has been used for medicinal purposes for centuries. Nowadays, major areas of pomegranate cultivation are India, Spain, Israel and the United States, where it has gained great economic impact due to their increasing consumption (Mertens-Talcott et al., 2006). In Chile, the areas with this crop have increased more than

${ }^{1}$ Universidad de Chile, Facultad de Ciencias Agronómicas, Casilla 1004, Santiago, Chile. "Corresponding autor (esepulve@uchile.cl).

${ }^{2}$ Universidad de Chile, Facultad de Ciencias Farmacéuticas, Vicuña Mackenna 20, Santiago, Chile.

${ }^{3}$ Instituto de Fermentaciones Industriales, Consejo Superior de Investigaciones Científicas (CSIC), Juan de la Cierva 3, 28006, Madrid, Spain.

Received: 30 December 2008.

Accepted:11 May 2009.
$65 \%$ in the last years. The pomegranate fruit is widely considered as a "healthy" fruit due to its biological actions, most of them attributed to its phenolic content (Lansky and Newman, 2007). Studies about pomegranate polyphenols have shown prevention of cardiovascular, cancer diseases and neurological damage in humans (Aviram et al., 2002; Kuskoski et al., 2004; Lansky and Newman, 2007). Flavonols and anthocyanins show anticarcinogenic, antimicrobial (Opara et al., 2009), antiinflammatory and antioxidant activities (Lansky and Newman, 2007). The phenyl propanoids as chlorogenic, caffeic and coumaric acids may be responsible of the inhibition of tumor initiation and development in rats (Huang et al., 2005).

Pomegranate juice has shown a 3-fold higher antioxidant capacity than red wine or green tea (Gil et al., 2000) and 2-, 6- and 8-fold higher capacity than 
those detected in grape/cranberry, grapefruit, and orange juices, respectively (Rosenblat and Aviram, 2006). This was attributed to its high content of polyphenols and, in particular, of ellagitannins, the major ones being punicalagins. Other phenolic compounds such as anthocyanins, condensed tannins, and flavonoids (quercetin, kaempferol and luteolin glycosides) are also present in pomegranates. Thus, pomegranate juice is recognized as an important source of anthocyanins, being the 3-glucosides and 3,5-diglucosides derivatives of delphinidin, cyanidin and pelargonidine the main ones (Gil et al., 2000).

Pomegranate juice can be used in beverages, for jellies, as flavouring and colouring agents, and for dietetic and prophylactic treatment purposes (Magerramov et al., 2007). The composition of pomegranate juice and its content of bioactive compounds, depend on factors such as species, variety, maturity index, and environmental and agronomic conditions (Gil et al., 1996; 2000; Miguel et al., 2004). This explains the interest in characterizing the pomegranate juices obtained from fruits grown in certain production areas. Gil and co-workers have extensively studied the anthocyanin composition of juices from Spanish (Gil et al., 1995a) and Tunisian (Gil et al., 1995b) pomegranates. Drogoudi et al. (2005) have characterized 20 Greek pomegranate accessions by using total phenolic indexes and antioxidant capacity measurements. Similarly, Tzulker et al. (2007) have reported data about the antioxidant activity, total phenolic indexes, amounts of major hydrolyzable tannins, and colour of pomegranates juices from 20 different accessions from Israel. Recently, Alighourchi et al. (2008) have characterized 15 Iranian pomegranate varieties by looking at their anthocyanin composition.

This works aims to determine the influence of the genotype on the phenolic composition, antioxidant capacity and colour of pomegranate juices from Chile.

\section{MATERIALS AND METHODS}

\section{Experimental material}

Pomegranate fruits of eight genotypes belonging to the germplasm collection of the University of Chile were harvested in April 2007. The genotypes selected are cultivated in different regions of Chile. The genotypes were identified with numbers from PG2 to PG9; five of them contained red arils, and three of them, pink arils (Table 1). The fruit characterization was done according to the Pomegranate Descriptors (Mars et al., 1997) in 10 fruits from each genotype that includes next tests:

Pomegranate juice. The pomegranate arils were squeezed by manual pressing and passed through muslin, avoiding the seed break. The $\mathrm{pH}$, soluble solids content ( ${ }^{\circ}$ Brix), titratable acidity (\% citric acid), and the ratio soluble solids/acidity (SS/Acidity) of the juices were determined according to AOAC (1996). The flavour of pomegranate is very dependent on the variety and maturity. It can be very sour or sweet or strong (Mars et al., 1997), with overall fruit flavour with a note of its tannins, which in this case is little noticed by the conditions of obtaining the juice that did not break the seed.

Determination of aril juice colour. The following color parameters of the juices prepared from the arils were determined at 420, 520 and $620 \mathrm{~nm}$ in a UVvis spectrophotometer (Beckman-Coulter DU 800. Fullerton, California. USA): color intensity (CI), color percentages of yellow (\% yellow), red (\% red) and blue ( $\%$ blue) and a variable responsible for the proportion of red produced by the flavilium cations (flavilium are salts of anthocyanins capable of reacting), pure red (\% dA) (Glories, 1984) and tone (Sudraud, 1958).

Table 1. Fruit color, characteristics of the different Chilean pomegranate genotypes and their corresponding juices.

\begin{tabular}{|c|c|c|c|c|c|c|}
\hline Genotype $^{1}$ & $\begin{array}{l}\text { Fruit } \\
\text { color }\end{array}$ & $\begin{array}{c}\text { Aril } \\
\text { color }^{2}\end{array}$ & pH & $\begin{array}{l}\text { Titratable acidity } \\
(\% \text { citric acid })\end{array}$ & ${ }^{\mathbf{O}}$ Brix & SS/Acidity ${ }^{2}$ \\
\hline PG2 & $4(\operatorname{Red})$ & Red & 3.0 & 2.90 & 17.4 & 6 (Sour) \\
\hline PG3 & $4(\operatorname{Red})$ & Red & 3.0 & 2.17 & 15.2 & 7 (Sour) \\
\hline PG4 & $4(\operatorname{Red})$ & Red & 2.9 & 2.43 & 17.0 & 7 (Sour) \\
\hline PG5 & $4(\operatorname{Red})$ & Red & 3.0 & 2.83 & 17.0 & 6 (Sour) \\
\hline PG6 & $4(\operatorname{Red})$ & Red & 3.0 & 2.26 & 15.8 & 7 (Sour) \\
\hline PG7 & 3 (Reddish-yellow) & Pink & 3.5 & 0.47 & 16.6 & 35 (Sweet) \\
\hline PG8 & 3 (Reddish-yellow) & Pink & 3.7 & 0.42 & 17.6 & 42 (Sweet) \\
\hline PG9 & 3 (Reddish-yellow) & Pink & 3.5 & 0.36 & 17.8 & 50 (Sweet) \\
\hline
\end{tabular}

SS: soluble solids. ${ }^{1}$ Genotype identification number. ${ }^{2}$ Pomegranate descriptors (Mars et al., 1997). 
Determination of total polyphenol content. Total polyphenols (TP) were determined with the FolinCiocalteu reagent according to the method of Singleton and Rossi (1965). Detection was achieved at $750 \mathrm{~nm}$ in a UV-vis spectrophotometer (Beckman-Coulter DU 800). The results were expressed as $\mathrm{mg}$ of gallic acid equivalents $\mathrm{L}^{-1}$. Determinations were carried out in duplicate.

Determination of total anthocyanin content. Total anthocyanins (TA) were quantified according to the variation of color in function of $\mathrm{pH}$, red in acid medium and weakly acidic bleaching in the form of pseudo-base, and were expressed as $\mathrm{mg} \mathrm{L}^{-1}$ of cyanidin 3-O-glucoside (Paronetto, 1977). Measurements were carried out in duplicate.

HPLC-DAD and HPLC/ESI-MS analysis of anthocyanins. High Performance Liquid Chromatography (HPLC) analysis was carried out on a Waters liquid chromatography system (Milford, Massachusetts, USA) equipped with a 600-MS controller, a 717 Plus autosampler, and a 996 photodiode-array detector (DAD). Separation was performed on a reverse-phase Nova-Pak $\mathrm{C}_{18}$ column (4 $\mu \mathrm{m} ; 250 \mathrm{~mm} \times 4.6 \mathrm{~mm}$, Waters). A gradient consisting of solvent A (water/formic acid, 90/10, v/v) and solvent B (methanol) was applied at a flow rate of $0.7 \mathrm{~mL} \mathrm{~min}^{-1}$ (Prieto et al., 2005). Thirty microliters of pomegranate juice, previously filtered through a $0.45 \mu \mathrm{m}$ membrane, were injected onto the column. Quantification was carried out by peak area measurements at $530 \mathrm{~nm}$. The content of these compounds was expressed as malvidin-3-glucoside chloride (Extrasynthèse, Genay, France) by an external standard calibration curve. Confirmation of anthocyanins structure was performed using a HPLC-electrospray ionization tandem mass spectrometry (HPLC/ESI-MS) (Hewlett-Packard series 1100, Palo Alto, California, USA). The electro spray tandem mass spectrometry (ESI) positive mode; scan range $100-1500 \mathrm{~m} / \mathrm{z}$. Nitrogen was used as nebulizing gas at $55 \mathrm{psi}$, a temperature of $350{ }^{\circ} \mathrm{C}$, a flow of $10 \mathrm{~L} \mathrm{~min}^{-1}$ and capillary voltage of $4000 \mathrm{~V}$. The same column and chromatographic conditions as for the HPLC-DAD analyses were used.

Antioxidant capacity. The radical scavenging activity of the extracts was determined by the oxygen-radical absorbance capacity (ORAC) method using fluorescein as a fluorescence probe. Briefly, the reaction was carried out at $37^{\circ} \mathrm{C}$ in $75 \mathrm{mM}$ phosphate buffer (pH 7.4) and the final assay mixture $(200 \mu \mathrm{L})$ contained fluorescein $(70 \mathrm{nM})$, 2,2'-azobis(2-methyl-propionamidine)-dihydrochloride $(12 \mathrm{mM}$ ), and antioxidant (Trolox $[1-8 \mu \mathrm{M}]$ or pomegranate juice at different concentrations). The plate was automatically shaken before the first reading and the fluorescence was recorded every minute for $98 \mathrm{~min}$. A Polarstar Galaxy plate reader (BMG Labtechnologies $\mathrm{GmbH}$, Offenburg, Germany) with 485-P excitation and 520-P emission filters was used. The equipment was controlled by the Fluostar Galaxy software version (4.110 ) for fluorescence measurement. Black 96-well untreated microplates (Nunc, Denmark) were used. 2,2'-Azobis (2-methyl-propionamidine)-dihydrochloride and Trolox solutions were prepared daily and fluorescein was diluted from a stock solution $(1.17 \mathrm{mM})$ in $75 \mathrm{mM}$ phosphate buffer (pH 7.4). Final ORAC values were expressed as mmol of Trolox equivalents $\mathrm{L}^{-1}$ of juice (Dávalos et al., 2004). All reaction mixtures were prepared in duplicate and at least three independent runs were performed for each sample.

\section{Statistical analysis}

The linear regression (95\% confidence limits) was used to determine the correlation between ORAC, total polyphenols (TP) and total anthocyanins (TA). Oneway ANOVA was used for establish differences between total polyphenols (TP), antioxidant capacity, total anthocyanins (TA), TP/TA, anthocyanins relations and colour parameters. Statgraphics plus 7.0 was used.

\section{RESULTS AND DISCUSSION}

The fruit and aril color of the different pomegranate genotypes and some chemical characteristics of the corresponding juices are shown in Table 1 . The genotypes differed in their peel and aril color and were characterized according to the descriptors proposed by Mars et al. (1997). They were grouped into a red-aril genotype group (PG2, PG3, PG4, PG5 and PG6) and a pink-aril genotype group (PG7, PG8 and PG9); the former gave to juices with lower $\mathrm{pH}(2.9-3.0)$ that were described as sour, and the latter produced juices with higher $\mathrm{pH}$ (3.5-3.7) and sweet properties. The ${ }^{\circ}$ Brix of the juices was from 15.2 to 17.8 showing independence of the genotype color (red or pink) (Table 1). The titrable acidity expressed as citric acid, ranged in sour pomegranates between 22.6 to 29.0 $\mathrm{g} \mathrm{L}^{-1}$ and in sweet pomegranates from 3.6 to $4.7 \mathrm{~g} \mathrm{~L}^{-1}$. Poyrazoglu et al. (2002) reported ranges between 4.48 to $17.3 \mathrm{~g} \mathrm{~L}^{-1}$, but differences between sweet or sour varieties was not mention.

The total polyphenol content (TP) of the different genotypes was between 676 and $1280 \mathrm{mg}$ gallic acid L-1 (Table 2). These values are lower than those reported by Pérez-Vicente et al. (2004) in a sweet juice from Spanish

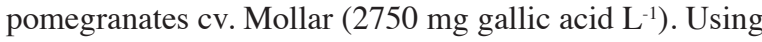
other phenolic standards, Gil et al. (2000) reported a phenolic content of $2117 \mathrm{mg} p$-coumaric acid $\mathrm{L}^{-1}$ for a fresh juice from arils, and Yunfeng et al. (2006) reported 
a value of $24.4 \mathrm{mg}$ tannic acid $\mathrm{g}^{-1}$ for the phenolic content of pomegranate pulp. The total anthocyanins (TA) of the pomegranate juices studied were between 170 and 1342 mg cyanidin-3-glucoside $\mathrm{L}^{-1}$ (Table 2 ), being lower for those genotypes with pink arils that gave juices of higher pH. Tzulker et al. (2007) reported values of total anthocyanin content from less than 100 to around $300 \mathrm{mg}$ cyanidin-3-glucoside $\mathrm{L}^{-1}$ for juices prepared from the arils of 29 Israeli pomegranate accessions. Other authors have reported that the anthocyanin content of pomegranates juices expressed as the sum of the individual anthocyanin contents, reached values of 6-120 mg cyanidin-3glucoside $\mathrm{L}^{-1}$ in juices from Tunisian pomegranates (Gil et al., 1995b) and of 162-387 mg cyanidin-3-glucoside $\mathrm{L}^{-1}$ in juices from fresh and frozen arils, and commercial juices from Californian pomegranates (Gil et al., 2000). All these values are in the range of that found in this paper for Chilean pomegranate aril juices since the richest-anthocyanin pomegranate genotype (PG4) shows an equivalent content of $483 \mathrm{mg}$ cyanidin-3-glucoside $\mathrm{L}^{-1}$ and the poorest-anthocyanin pomegranate genotype (PG7) shows an equivalent content of $61 \mathrm{mg}$ cyanidin-3glucoside $\mathrm{L}^{-1}$.

The antioxidant capacity of the pomegranate juices measured as ORAC values was between 12.7 to 24.4 mmol Trolox $\mathrm{L}^{-1}$ (Table 2), similar results were obtained for pomegranate juice $\left(25.0 \pm 1.0 \mu \mathrm{mol}\right.$ of $\mathrm{TE} \mathrm{mL}^{-1}$ by Seeram et al. (2008) and higher for acetone extracts prepared from the edible portions of pomegranate fruits

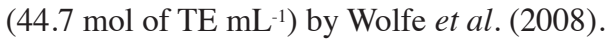

A significant correlation $(\mathrm{p}<0.05)$ between the ORAC values with the total polyphenol content $(r=0.95)$, with total anthocyanin content $(\mathrm{r}=0.89)$ and with $\mathrm{TP} /$ TA relationship $(r=-0.85)$ was found. The polyphenols content showed the better correlation. These results indicate that the antioxidant potential of the Chilean juices from aril pomegranates is related too with their level of anthocyanins. In a previous study, Tzulker et al. (2007) also showed positive significant correlations between the antioxidant capacity (evaluated by the FRAP method) and the total polyphenol and anthocyanin contents in juices prepared from the arils of 29 Israeli pomegranate accessions. These same authors found that the levels of hydrolyzable tannins (punicalagin, punicalin and gallagic acids) present in the pomegranate juices manually obtained from the arils, did not correlate to the juice antioxidant capacity due to their relative low tannin content in comparison to that in squeezed juices (Tzulker et al., 2007). However, the contribution of rind hydrolyzable tannins to the juice antioxidant capacity turns majority in commercial pomegranate juices, due to their relevant tannin content $\left(417-557 \mathrm{mg} \mathrm{L}^{-1}\right.$; Gil et al., 2000), which explains the higher antioxidant activity (3-fold) of commercial juices in comparison to the juices obtained by hand pressing the arils (Gil et al., 2000).

When the genotypes were grouped by colour in Table 2, we observed that the antioxidant capacity and TA values were significantly higher for the red genotypes juices (PG2-PG6) than for the pink genotypes juices (PG7-PG9) and TP/TA relationship was significantly lower ratio for the red pomegranates varieties. Also, the higher ORAC values, the lower TP/TA ratio, due to a different anthocyanins content between the genotypes. In this context, the relation TP/TA could be a good marker to differentiate the genotypes studied.

Color is one of the most important parameters when making a sensorial evaluation of food quality. The bright color of pomegranate juice is due to

Table 2. Total polyphenols (TP), antioxidant capacity, total anthocyanins (TA) and TP/TA relationship of juices from different Chilean pomegranate genotypes.

\begin{tabular}{|c|c|c|c|c|}
\hline Genotype $^{1}$ & $\begin{array}{c}\text { Total } \\
\text { polyphenols (TP) } \\
\end{array}$ & $\begin{array}{c}\text { Antioxidant capacity } \\
\text { ORAC value } \\
\end{array}$ & $\begin{array}{c}\text { Total } \\
\text { anthocyanins (TA) }\end{array}$ & TP/TA \\
\hline & mg gallic acid $\mathrm{L}^{-1}$ & mmol Trolox $\mathrm{L}^{-1}$ & mg cyanidin-3-glucoside $\mathrm{L}^{-1}$ & \\
\hline PG2 & 1236 & $24.4 \mathrm{red}$ & 984 & 1.25 \\
\hline PG3 & 1055 & $21.2 \mathrm{red}$ & 749 & 1.40 \\
\hline PG4 & 1215 & $22.7 \mathrm{red}$ & 1328 & 0.91 \\
\hline PG5 & 1280 & $23.3 \mathrm{red}$ & 915 & 1.39 \\
\hline PG6 & 1195 & $22.1 \mathrm{red}$ & 588 & 2.03 \\
\hline PG7 & 720 & 12.7 pink & 168 & 4.28 \\
\hline PG8 & 1075 & 16.8 pink & 219 & 4.91 \\
\hline PG9 & 676 & 13.1 pink & 204 & 3.31 \\
\hline PG2-PG6 $(x \pm \sigma)$ & $1196 \pm 85 a$ & $22.74 \pm 1.21 \mathrm{a}$ & $913 \pm 278 \mathrm{a}$ & $1.39 \pm 0.40 \mathrm{a}$ \\
\hline PG7-PG9 $(x \pm \sigma)$ & $824 \pm 219 a$ & $14.2 \pm 2.26 b$ & $197 \pm 26 b$ & $4.16 \pm 0.80 \mathrm{~b}$ \\
\hline
\end{tabular}

${ }^{1}$ Genotype identification number. Values followed by different letters are significantly different for genotype groups for each analysis $(\mathrm{p}<0.05)$. 
anthocyanins. Table 3 shows the color characteristics of the juices obtained by soft pressing of the arils from the different pomegranate genotypes. The pomegranate juices from red-aril genotypes (PG2 to PG6) showed significant greater color intensity $(\mathrm{CI})$ than the juices from pinkaril genotypes (PG7 to PG9), 0.75-1.96 and 0.12-0.16, respectively, significant higher \% red (70.9-77.7 and 60.466.6 , respectively) and significant higher dA\% (pure red) (79.5-85.6 and 67.2-74.9, respectively), which was related to their higher total anthocyanin content. Genotypes PG2PG6 also led to juices with significant lower tone $(0.25$ 0.37), significant $\%$ yellow (19.6-26.4) and significant $\%$ blue (2.6-2.7) than genotypes PG7-PG9 (0.44-0.58 for tone, 29.3-34.8 for \% yellow and 4.1-4.8 for \% blue parameters). In juices from Israeli pomegranates, Tzulker et al. (2007) reported a juice color index close to 50 for accessions with red arils, and around 35 for accessions with white or pale pink arils.

Table 4 shows the anthocyanins profile of Chilean pomegranate juices. The anthocyanins were identified according to their mass spectra (Table 4): delphinidin3,5-diglucoside (7.22 min); cyanidin-3,5-diglucoside + delphinidin-3-glucoside (9.99 $\mathrm{min})$; pelargonidin-3,5diglucoside (13.38 min); cyanidin-3-glucoside (16.86 $\mathrm{min}$ ) and pelargonidin-3-glucoside (20.52 min) (Figure 1).

Figure 1 depicts the HPLC-DAD chromatogram corresponding to the pomegranate juice from genotype PG2.

The complete mass spectra of the anthocyanins identified in pomegranate were previously reported (Gil et al., 2000), except for pelargonidin 3-glucoside, which correspond to $[\mathrm{M}]^{+} 433, \mathrm{~m} / \mathrm{z} 271$ (Table 4). As expected, these Chilean pomegranate juices show the same anthocyanin profile as those reported by Miguel et al. (2004) for 'Assaria' pomegranate, by Gil et al. (2000) for 'Wonderful' pomegranate, and by Noda et al. (2002) who reported that delphinidin-3,5-diglucoside was a major anthocyanin in juices from Californian pomegranates. In a recent paper, Alighourchi et al. (2008) reported the following anthocyanin amounts in 15 Iranian pomegranate varieties: delphinidin-3-glucoside (2.19-16.29 $\left.\mathrm{mg} \mathrm{L}^{-1}\right)$, delphinidin-3,5-diglucoside (2.36$\left.63.07 \mathrm{mg} \mathrm{L}^{-1}\right)$, pelargonidin 3-glucoside $(0.26-1.36 \mathrm{mg}$ $\left.\mathrm{L}^{-1}\right)$, pelargonidine 3,5-diglucoside $\left(0.01-8.11 \mathrm{mg} \mathrm{L}^{-1}\right)$,

Table 3. Color characteristics of juices from different Chilean pomegranate genotypes.

\begin{tabular}{lcccccc}
\hline Genotype $^{1}$ & CI $^{2}$ & Tone & \% yellow & \% red & \% blue & dA \% $^{3}$ \\
\hline PG2 & 1.17 & 0.30 & 22.3 & 75.1 & 2.6 & 83.5 \\
PG3 & 0.85 & 0.34 & 24.5 & 72.8 & 2.7 & 81.4 \\
PG4 & 1.96 & 0.25 & 19.6 & 77.7 & 2.7 & 85.6 \\
PG5 & 1.21 & 0.30 & 22.3 & 75.1 & 2.6 & 83.4 \\
PG6 & 0.75 & 0.37 & 26.4 & 70.9 & 2.6 & 79.5 \\
PG7 & 0.16 & 0.44 & 29.3 & 66.6 & 4.1 & 74.9 \\
PG8 & 0.14 & 0.58 & 34.8 & 60.4 & 4.8 & 67.2 \\
PG9 & 0.12 & 0.47 & 30.6 & 64.8 & 4.6 & 72.9 \\
PG2-PG6 $(\mathrm{x} \pm \sigma)$ & $1.19 \pm 0.47 \mathrm{a}$ & $0.31 \pm 0.045 \mathrm{a}$ & $23.02 \pm 2.57 \mathrm{a}$ & $74.32 \pm 2.58 \mathrm{a}$ & $2.64 \pm 0.055 \mathrm{a}$ & $82.68 \pm 2.31 \mathrm{a}$ \\
PG7-PG9 $(\mathrm{x} \pm \sigma)$ & $0.14 \pm 0.02 \mathrm{~b}$ & $0.50 \pm 0.074 \mathrm{~b}$ & $31.57 \pm 2.87 \mathrm{~b}$ & $63.9 \pm 3.19 \mathrm{~b}$ & $4.5 \pm 0.36 \mathrm{~b}$ & $71.67 \pm 3.99 \mathrm{~b}$ \\
\hline
\end{tabular}

${ }^{1}$ Genotype identification number. ${ }^{2}$ Color intensity. ${ }^{3}$ Pure red.

Values followed by different letters are significantly different for genotype groups for each analysis $(\mathrm{p}<0.05)$.

Table 4. Anthocyanins profile of Chilean pomegranate juices identified by High Performance Liquid ChromatographyElectrospray Ionization Tandem Mass Spectrometry (HPLC/ESI-MS).

\begin{tabular}{llc}
\hline Retention time (min) & Anthocyanidin-glucoside & {$[\mathbf{M}]^{+}$fragments m/z } \\
\hline 7.22 & Delphinidin-3.5-diglucoside & {$[\mathrm{M}]^{+}$627, m/z 465.303 } \\
9.99 & Cyanidin-3.5-diglucoside & {$[\mathrm{M}]^{+} 611, \mathrm{~m} / \mathrm{z} 449.287$} \\
9.99 & Delphinidin-3-glucoside & {$[\mathrm{M}]^{+} 465, \mathrm{~m} / \mathrm{z} 303$} \\
13.38 & Pelargonidin-3.5-diglucoside & {$[\mathrm{M}]^{+} 595, \mathrm{~m} / \mathrm{z} 433.271$} \\
16.86 & Cyanidin-3-glucoside & {$[\mathrm{M}]^{+} 449, \mathrm{~m} / \mathrm{z} 287$} \\
20.52 & Pelargonidin-3-glucoside & {$[\mathrm{M}]^{+}$433, m/z 271 } \\
\hline
\end{tabular}

$[\mathrm{M}]^{+}$: molecular ion; $\mathrm{m} / \mathrm{z}$ : A unitless notation often used for the independent variable in a mass spectrum. 


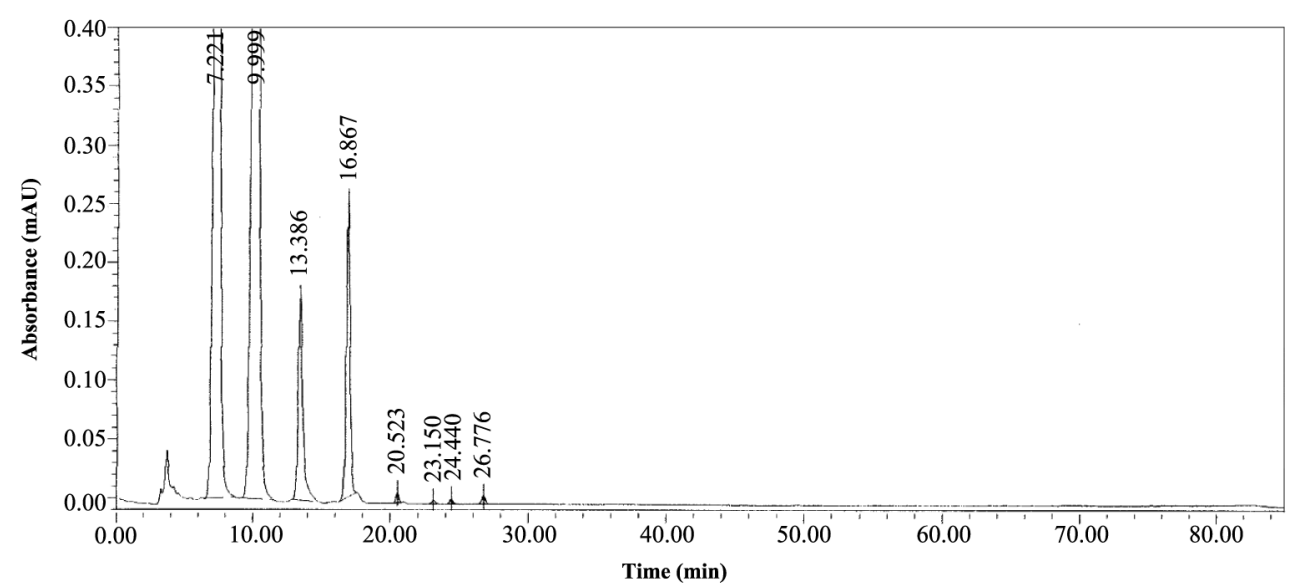

Nova-Pak $\mathrm{C}_{18}$ column; mobile phase solvent $\mathrm{A}$ (water/formic acid, 90/10, v/v) and solvent $\mathrm{B}$ (methanol) in gradient, flow rate of $0.7 \mathrm{~mL}$ min ${ }^{-1}$.

Figure 1. Anthocyanin chromatogram of the pomegranate juice corresponding to genotype PG2.

cyanidin 3-glucoside $\left(5.78-30.38 \mathrm{mg} \mathrm{L}^{-1}\right)$ and cyanidin 3,5-diglucoside (4.39-166.32 $\left.\mathrm{mg} \mathrm{L}^{-1}\right)$.

In an attempt to characterize the different Chilean pomegranate genotypes, different relationships between the main anthocyanins were calculated: Dp/Cy, Dp/ $\mathrm{Pg}$, and $\mathrm{Pg} / \mathrm{Cy}$, where $\mathrm{Dp}$ was the sum of the amounts $\left(\mathrm{mg} \mathrm{L} \mathrm{L}^{-1}\right)$ of delphinidin-3-glucoside and delphinidin3,5-diglucoside, Cy corresponded to the sum of the amounts $\left(\mathrm{mg} \mathrm{L}^{-1}\right)$ of cyanidin 3-glucoside and cyanidin 3,5-diglucoside, and $\mathrm{Pg}$ was the sum of the amounts $\left(\mathrm{mg} \mathrm{L}^{-1}\right)$ of pelargonidin 3-glucoside and pelargonidine 3,5-diglucoside (Table 5). The means for the red (PG2 to PG6) and pink (PG7 to PG9) genotypes are also included, as well as the ratio for the means of both genotype groups [(PG7 to PG9)/(PG2 to PG6)]. The relationship PgCy was significatively $(\mathrm{p}<0.01)$ higher in the pink genotypes, suggesting that it relation could be useful to differentiate the two groups of genotypes (red and pink) studied. The anthocyanin relationships also appear to be useful in the characterization of a particular pomegranate genotype, such as PG9 by the Dp/Cy relationship. But, in any case, more determinations from other seasons are required in order to confirm these first results about characterization of Chilean pomegranate genotypes attending to their anthocyanin composition.

Table 5. Relationships between concentrations of the main anthocyanidins identified in Chilean pomegranate juices by High Performance Liquid Chromatography-Electrospray Ionization Tandem Mass Spectrometry (HPLC/ESI-MS).

\begin{tabular}{|c|c|c|c|}
\hline Genotype & $\mathrm{Dp} / \mathrm{Cy}$ & $\mathrm{Dp} / \mathrm{Pg}$ & $\mathrm{Pg} / \mathrm{Cy}$ \\
\hline & & $-\mathrm{mg} \mathrm{L}^{-1}$ & - \\
\hline PG2 & 7.89 & 6.79 & 1.16 \\
\hline PG3 & 7.93 & 7.12 & 1.11 \\
\hline PG4 & 5.17 & 5.43 & 0.95 \\
\hline PG5 & 3.96 & 3.52 & 1.12 \\
\hline PG6 & 4.81 & 4.62 & 1.04 \\
\hline PG7 & 9.08 & 6.40 & 1.41 \\
\hline PG8 & 6.16 & 4.25 & 1.44 \\
\hline PG9 & 10.93 & 8.45 & 1.29 \\
\hline PG2-PG6 $(x \pm \sigma)$ & $5.95 \pm 1.84 \mathrm{a}$ & $5.49 \pm 1.49 \mathrm{a}$ & $1.08 \pm 0.08 \mathrm{a}$ \\
\hline PG7-PG9 $(x \pm \sigma)$ & $8.72 \pm 2.40 \mathrm{a}$ & $6.36 \pm 2.10 \mathrm{a}$ & $1.38 \pm 0.08 b$ \\
\hline (PG7-PG9)/(PG2-PG6) & 1.46 & 1.15 & 1.27 \\
\hline
\end{tabular}

Dp: sum of the amounts of delphinidin-3-glucoside and delphinidin-3,5-diglucoside; Cy: sum of the amounts of cyanidin 3-glucoside and cyanidin 3,5-diglucoside; Pg: sum of the amounts of pelargonidin 3-glucoside and pelargonidine 3,5-diglucoside.

Values followed by different letters are significantly different for genotype groups for each analysis $(\mathrm{p}<0.05)$. 


\section{CONCLUSIONS}

This paper reports the first data about the phenolic composition and phenolic-related properties of Chilean pomegranate juices. Great differences in bioactive component content as well as in $\mathrm{pH}$, color and anthocyanin concentration are shown among the red and pink Chilean pomegranate genotypes studied. The red-aril genotypes show significantly higher values in antioxidant capacity, total anthocyanins content and total polyphenols/total anthocynins relationships than the pink-aril genotypes. The last relationships and $\mathrm{Pg} / \mathrm{Cy}$ could be useful in the analytical characterization of Chilean pomegranate genotypes, as well as in the differentiation with other juices containing anthocyanins. The information reported in this paper increases the general knowledge about the natural variation of antioxidant activity, phenolic composition and color in pomegranate fruits from different production areas and may also be useful for addressing local-farmer choices for high quality products.

\section{ACKNOWLEDGEMENTS}

The authors will thanks to the Grant: DI MULT 06/262, Universidad de Chile and 17/07-08 CSIC-Universidad de Chile, Ministerio de Educación y Ciencia (MEC), 2006CL0028 Spain-Chile, Ministerio de Ciencia y Tecnología/INIA VIN03-006-C2-1, Spain. The authors are grateful to I. Izquierdo for her technical assistance.

\section{RESUMEN}

Influencia del genotipo en la composición de antocianos, capacidad antioxidante y color de jugos de granada (Punica granatum L.) cultivadas en Chile. El contenido de compuestos bioactivos del jugo de granada (Punica granatum L.) es variable y depende de manejos culturales, factores genéticos y grado de madurez del fruto. En Chile, las áreas destinadas a este cultivo han aumentado más de un $65 \%$ en los últimos 5 años. Los objetivos fueron determinar la composición fenólica, capacidad antioxidante y parámetros cromáticos de los jugos provenientes de ocho genotipos de frutos de granada cultivados en Chile (PG2PG9), de arilos rojos (PG2 a PG6) y rosados (PG7 a PG9).

Se determinó color del jugo, contenido de polifenoles totales (utilizando el reactivo de Folin-Ciocalteu), antocianos totales por diferencias de absorbancias a $\mathrm{pH}$ ácido y tamponado del jugo y capacidad antioxidante (capacidad de absorción de radicales de oxígeno, ORAC). Los antocianos se identificaron y cuantificaron utilizando HPLC-DAD y HPLC/ESI-MS, los resultados se expresaron en cianidín-3-glucósido. Las diferencias entre los polifenoles totales (TP), capacidad antioxidante, antocianos totales (TA), se analizaron aplicando ANDEVA, utilizando el programa Statgraphics plus 7.0. Los genotipos PG2-PG6 (arilos rojos), muestran mayores valores de polifenoles totales (1055-1280 $\left.\mathrm{mg} \mathrm{L}^{-1}\right)$ y antocianos (588$\left.1328 \mathrm{mg} \mathrm{L}^{-1}\right)$ y mayores valores de ORAC $(21,2-24,4$ $\mu$ mol Trolox $\mathrm{mL}^{-1}$ ) que los de arilos rosados PG7-PG9 $\left(12,7-16,8 \mu \mathrm{mol}\right.$ Trolox $\left.\mathrm{mL}^{-1}\right)$. Estos genotipos presentan mayores valores de $\mathrm{pH}(3,5-3,7)$. Los compuestos antociánicos identificados en el jugo fueron los derivados 3-glucósido y 3,5-diglucósido de la delfinidina, cianidina y pelargonidina, encontrándose diferencias, en sus contenidos relativos, entre los genotipos estudiados. Las relaciones entre TP/TA y $\mathrm{Pg} / \mathrm{Cy}$ (pelargonidina 3-glucósido y pelargonidina 3,5-diglucósido/cianidina 3-glucósido y cianidina 3,5-diglucósido) pueden ser útiles en la caracterización de las granadas cultivadas en Chile, así como para diferenciarlas de otros jugos que contienen antocianos.

Palabras clave: Punica granatum, polifenoles, compuestos bioactivos.

\section{LITERATURE CITED}

Alighourchi, H., M. Barzegar, and S. Abbasi. 2008. Anthocyanins characterization of 15 Iranian pomegranate (Punica granatum L.) varieties and their variation after cold storage and pasteurization. Eur. Food Res. Technol. 227:881-887.

AOAC. 1996. Official methods of analysis of AOAC International. $16^{\text {th }}$ ed. Association of Official Analytical Chemists (AOAC), Gaithersburg, Maryland, USA.

Aviram, M., L. Dornfeld, M. Kaplan, R. Coleman, D. Gaitini, S. Nitecki, et al. 2002. Pomegranate juice flavonoids inhibit low-density lipoprotein oxidation and cardiovascular diseases: studies in atherosclerotic mice and in humans. Drugs Exp. Clin. Res. 28:49-62.

Dávalos, A., C. Gómez-Cordovés, and B. Bartolomé. 2004. Extending applicability of the oxygen radical absorbance capacity (ORAC-fluorescein) assay. J. Agric. Food Chem. 52:48-54.

Drogoudi, P.D., C. Tsipouridis, and Z. Michailidis. 2005. Physical and chemical characteristics of pomegranates. HortScience 40:1200-1203.

Gil, M.I., J. Cherif, N. Ayed, F. Artés, and F. TomásBarberán. 1995b. Influence of cultivar, maturity stage and geographical location on the juice pigmentation of Tunisian pomegranates. Z. Lebensm. Unters. Forsch. 201:361-364.

Gil, M.I., C. García-Viguera, F. Artes, and F.A. TomásBarberán. 1995a. Changes in pomegranate juice pigmentation during ripening. J. Sci. Food. Agric. 68:77-81. 
Gil, M.I., R. Sánchez, J. Ginés-Marín, and F. Artes. 1996. Quality changes in pomegranates during ripening and cold storage. Z. Lebensm. Unters. Forsch. 202:481-485.

Gil, M.I., F. Tomas-Barberán, B. Hess-Pierce, D. Holcroft, and A. Kader. 2000. Antioxidant activity of pomegranate juice and its relationship with phenolic composition and processing. J. Agric. Food Chem. 48:4581-4589.

Glories, Y. 1984. La couleur des vins rouges 2. Mesure, origine et interprétation. Connais. Vigne Vin 18:253-271.

Huang, T.H.S., G. Peng, B.P. Kota, G.Q. Li, J. Yamahara, B.D. Roufogalis, and Y. Li. 2005. Pomegranate flower improves cardiac lipid metabolism in a diabetic rat model: Role of lowering circulating lipids. Brit. J. Pharmacol. 145:767-774.

Kuskoski, M., A. Asuero, M. García-Parilla, A. Troncoso, y R. Fett. 2004. Actividad antioxidante de pigmentos antociánicos. Cienc. Tecnol. Aliment., Campinas 24:691-693.

Lansky, E.P., and R.A. Newman. 2007. Punica granatum (pomegranate) and its potential for prevention and treatment of inflammation and cancer. J. Ethnopharmacol. 109:177-206.

Magerramov, M.A., A.I. Abdulagatov, N.D. Azizov, and I.M. Abdulgatov. 2007. Effect of temperature, concentration, and pressure on the viscosity of pomegranate and pear juice concentrates. J. Food Eng. 80:476-489.

Mars, M., P. Melgarejo, A. Amorós, and R. Martínez. 1997. Pomegranate descriptors. 20 p. Collaborative Working Group on Underutilized Fruit Crops in the Mediterranean Region. April. 1997. CIHEAM. Instituto Agronómico Mediterráneo de Zaragoza (IAMZ), Zaragoza, Spain.

Mertens-Talcott, S.U., P. Jilma-Stohlawetz, J. Ríos, L. Hingorani, and H. Derendorf. 2006. Absorption, metabolism and antioxidant effects of pomegranate (Punica granatum) polyphenols after ingestion of a standardized extract in healthy human volunteers. J. Agric. Food Chem. 54:8956-8961.

Miguel, G., C. Fontes, D. Antunes, A. Neves, and D. Martins. 2004. Anthocyanin concentration of "Assaria" pomegranate fruits during different cold storage conditions. J. Biomed. Biotechnol. 5:338-342.

Noda, Y., T. Kaneyuki, A. Mori, and L. Packer. 2002. Antioxidant activities of pomegranate fruit extract and its anthocyanidins: Delphinidin, Cyanidin, and Pelargonidin. J. Agric. Food Chem. 50:166-171.
Opara, L.U., M.R. Al-Ani, and Y.S. Al-Shuaibi. 2009. Physico-chemical properties, vitamin $\mathrm{C}$ content and antimicrobial properties of pomegranate fruit (Punica granatum L.). Food Bioprocess Technol. 2:315-321.

Paronetto, L. 1977. Polifenoli e tecnica enologica. p. 115116. Selepress, Milan, Italy.

Pérez-Vicente, A., P. Serrano, P. Abellán, and C. GarcíaViguera. 2004. Influence of packaging material on pomegranate juice colour and bioactive compounds, during storage. J. Sci. Food Agric. 84:639-644.

Poyrazoglu, E., V. Gokmen, and N. Artik. 2002. Organic acids and phenolic compounds in pomegranates (Punica granatum L.) grown in Turkey. J. Food Comp. Analysis 15: 567-575.

Prieto, M., B. Bartolomé, and C. Gómez-Cordovés. 2005. Anthocyanin composition, colour, and antioxidant capacity of a red wine aged in barrels or macerated with oak chips. p. 249-250. In Advances in Enological Sciences and Technologies-1, Valladolid. University of Valladolid, Palencia, Spain.

Rosenblat, M., and M. Aviram. 2006. Antioxidative properties of pomegranate: In vitro studies. p. 31-43. In Seeram, N.P., and D. Heber (eds.) Pomegranate: Ancient roots to modern medicine. Taylor and Francis Group, New York, USA.

Seeram, N.P., M. Aviram, Y. Zhang, S. Henning, L. Feng, M. Dreher, and D. Heber. 2008. Comparison of antioxidant potency of commonly consumed polyphenol-rich beverages in the United States. J. Agric. Food Chem. 56:1415-1422.

Singleton, V.L., and J.A. Rossi. 1965. Colorimetry of total phenolics with phosphomolybdic-phosphotungstic acid reagents. Am. J. Enol. Vitic. 16:144-158.

Sudraud, P. 1958. Interpretation des courbes d'absorption des vins rouges. Ann. Technol. Agric. 7:203-208.

Tzulker, R., I. Glazer, I. Bar-Ilan, D. Holland, M. Aviram, and R. Amir. 2007. Antioxidant activity, polyphenols content, and related compounds in different fruit juices and homogenates prepared from 29 different pomegranate accessions. J. Agric. Food Chem. 55:9559-9570.

Wolfe, L.K., X. Kang, X. He, M. Dong, Q. Zhang, and R.H. Liu. 2008. Cellular antioxidant activity of common fruits. J. Agric. Food Chem. 56:8418-8426.

Yunfeng, L., G. Changjiang, J. Yang, J. Wei, J. Xu, and S. Cheng. 2006. Evaluation of antioxidant properties of pomegranate peel extract in comparison with pomegranate pulp extract. Food Chem. 96:254-260. 